Antarctic trouble ahead?

The welcome end of the Falklands war may yet herald trouble for the Antarctic Treaty.

The shooting may have stopped in the Falkland Islands but the state of war continues. Britain says that the exclusion zone in which Argentine ships will be regarded as hostile will remain in place around the Falklands until it is assured that hostilities are at an end. But the government of Argentina, in the throes of its postwar reconstruction, cannot yet make up its mind what should be done. Whatever government emerges in Buenos Aires, however, the Argentine claim of sovereignty over the Falklands is unlikely simply to be abandoned. The flat contradiction of that cry by the British government's insistence that the Falklands are a British possession - reinforced by the removal of an Argentine party from Thule in the South Sandwich Islands at the weekend - is a depressing omen for the future. The best chance that civility can return to Anglo-Argentine relations is that the issue of sovereignty should be put on ice, but the diplomats will be hard pressed to devise an agreement to that effect which each government can stomach. The prospect is that the negotiations that eventually take place will be as protracted and frustrating as those which preceded the war - and will be embittered because of it. The hope must be that this souring of relations will not spill over into the delicate negotiations now taking place under the umbrella of the Antarctic Treaty.

Britain and Argentina are key players in the circle of 14 nations that govern the region south of 60 degrees south latitude through the treaty, which came into effect in 1961. In the past few years, this group, building on a long history of mutual cooperation in the Antarctic, has begun a chain of decisions about how to dispose of the Antarctic region's food and mineral resources. Two critical meetings on these topics have taken place this month and it is a measure of the importance all parties attach to the subject that the meetings went forward despite the Falklands war.

The earlier meeting, at Hobart in Tasmania, was the first of the new commission established under the 1980 convention for the conservation of Antarctic marine living resources. Britain's scientific contribution, particularly that of Richard M. Laws, director of the British Antarctic Survey, has been important in establishing the concept that there is a serious risk that Antarctic krill - the region's principal food resource - could be overfished. Indeed, British research has shown that overfishing of some species of Antarctic fish has already taken place. Overfishing of krill (probably by the Soviet Union and Japan, which took perhaps as much as 500,000 tonnes last season) could imperil the higher life forms of the Antarctic that depend on krill as their main food source. Most endangered would be Antarctic whale stocks, already depleted by whaling earlier in the century. Formally, the commission could crack down on countries accused of overfishing, but the meeting in Hobart was also intended to establish a new scientific committee. This group is crucial to the success of the new convention, for it is the technical link that will determine when krill are being overfished. Since British research has contributed so fully to the understanding of Antarctic marine resources, it had been expected that Laws would become its first chairman. The fact that his election has now been vetoed is a clear sign of fall-out from the Falklands, and a warning that the amity of the treaty is in danger.

The second meeting, in Wellington, New Zealand, has been planned to make a start on the thorny question of the ultimate disposition of Antarctic minerals. How can exploitation be made compatible with the original treaty? The continent has huge continental shelves (the Weddell Sea floor is the size of Venezuela) with thick sedimentary deposits that may contain hydrocarbon deposits for example. One snag is that nobody agrees which country owns which part of Antarctica. Indeed, Britain, Argentina and Chile have overlapping and conflicting claims to the part south of South America, including the Weddell Sea. Whether it will be possible to allocate rights to mineral resources before the ownership of the land has been settled is problematical, but there is no shortage of technical questions to be hammered out in advance - the technical steps that must be taken to avoid pollution of this unique environment for example.

The most obvious danger is that with the parties to the Falklands dispute also prominent signatories of the treaty, mischief-making will break out. Of claimants on the Antarctic, Argentina is among the most clamant, and has even sought to reinforce its claims by sending pregnant women to Antarctica so that their babies can be born Antarctic Argentines. Hitherto, Britain has been by comparison a modest claimant, saying that its formal claims in Antarctica are intended more as declarations of trusteeship than as old-fashioned territorial claims. It is to be hoped that the experience of the past three months will not have given the British too keen an appreciation of the pleasures of possession. Either way, since all decisions within the Antarctic Treaty must be taken unanimously, it will be easy for Argentina, Britain or some third party effectively to veto an unwelcome proposal by saying that the question cannot be settled until ownership has been resolved. By the convention signed in 1980, it has been agreed that something should be done to exploit marine resources sensibly, but nothing has been decided about minerals.

The meeting in Wellington has been made necessary by the need to forestall unwelcome activities in the Antarctic. The most obvious danger is that a failure to agree a set of rules will let in a host of cowboys. The best but also the most likely outcome is that there should be a moratorium on mineral exploitation until procedures have been worked out for telling how the profits (if any) should be distributed. But it should be fresh in the minds of member states that a very similar question occupied the conference on the Law of the Sea for the best part of a decade. It is not too soon to start on this negotiation.

\section{Ships will go down}

\section{The Falklands conflict seems to have heartened the British naval lobby. It should not.}

After its successful reoccupation of the Falkland Islands, the British government and especially the defence department finds itself engaged in a war that could politically or financially more damaging - a war with the most loyal of its supporters in the past three months, the members of the Navy lobby. Like the Falklands war, the war about naval policy has been rumbling away for months and even years, on one reckoning since in the 1960s the British government gave up the pretence of keeping a strong strategic force east of Suez and stopped building large aircraft carriers soon afterwards. More recently, however, the present government has had to forgo the services of one Navy minister (Mr Michael Steed) who resigned because he thought the British Navy was being starved of funds (Trident nuclear submarines not counting) while Mr John Nott, the present defence minister, appears to have succeeded Mr Francis Pym (by accident, now Foreign Secretary) because he showed more willingness to tell the Navy that they cannot have all the equipment they would like. Inevitably, in the weeks following a successful naval engagement, the case for building more ships is being loudly put.

It should be resisted and Mr Nott, to his credit, appears to be prepared to do just that. For the lessons of the Falklands war (which touch other modern governments than the British) run both ways. The task force to the Falklands could not have been mounted without ships, and large numbers of them, a large proportion of them fighting ships. That is one strike for the Navy lobby. But the recent conflict also showed that ships are vulnerable - part of the reason why successive British governments, whatever their first inclinations, have been cool about naval vessels as effective contributors to defence. (That they appear to burn so easily and well is nevertheless surprising.) Moreover, surface ships are likely for a long time to be more easily detected as floating metal objects on the surface of a foreign element, water, than they will be able to defend themselves with counter-measures. For the Navy lobby, that objection will not easily be turned. 